(RESEARCH ARTICLE)

\title{
Characteristic of $\mathrm{CO} 1$ gene in "Bonita", one of the female tiger Panthera tigris sumatrae in East Sumatra
}

\author{
Ashrifurrahman 1, Fadhlullah Aqil ${ }^{1}$, Ericca Cynthia ${ }^{1}$, Simamora Saruedi ${ }^{2}$, Novarino Wilson ${ }^{1}$ and Roesma \\ Dewi Imelda ${ }^{1, *}$
${ }^{1}$ Biology Department, Faculty of Mathematics and Natural Sciences, Andalas University, 25163 Padang, West Sumatra, Indonesia.
${ }^{2}$ Dharmasraya Sumatran Tiger Rehabilitation Center - ARSARI Djojohadikusumo Foundation (PR-HSD Yayasan ARSARI Djojohadikusumo), Dharmasraya, West Sumatra.

Publication history: Received on 23 August 2019; revised on 28 September 2019; accepted on 01 October 2019

Article DOI: https://doi.org/10.30574/wjarr.2019.4.2.0055

\begin{abstract}
Based on the IUCN Red List, Panthera tigris sumatrae or Sumatran Tiger holds the status of Critical (Critically Endangered /CR) species with an estimated population of only 371 individuals in the wild. Illegal hunting and trade are one of the causes that led to population decline drastically. Conventional forensic investigation such as morphological data collection is difficult to do because the sample has been degraded or mixed with other animal body parts. DNA barcode is an actual method that utilizes DNA for species identification based on the gene markers of living things. DNA barcode usually uses a DNA nucleotide sequence of genes that is different between species and almost unchanged in that species. The gene is cytochrome oxidase subunit 1 (CO1). Here we report the results of the characterization of the C01 gene for DNA barcoding from one of the Sumatran tigers with an individual identity called Bonita caught in Riau province and released after being rehabilitated. This research has been able to characterize the C01 Bonita gene along 435 nucleotides. That length of the nucleotide can be used as a Bonita barcode with the change in the eighth amino acid, Leucine to Proline with the 23rd nucleotide mutation (CTG $\rightarrow$ CCG). CO1 can distinguish individuals in intra-species, which in the eighth amino acid from other Panthera tigris is Leucine. CO1 gene can differentiate between species analyzed in this study with genetic distances greater than $8.3 \%$.
\end{abstract}

Keywords: DNA barcoding; Felidae; NCBI; PCR

\section{Introduction}

Sumatran tiger is one of the six subspecies of Panthera tigris that still survive, and the only ones still exist in Indonesia. Sumatran tigers are a natural predator, but their population has declined [1]. In 1978 the population estimated were about 1,000 individuals [2]. In 1990 it was estimated that 400-500 individuals left in the wild [3]. The declining of the Sumatran tiger populations caused by several factors, including the increase of illegal trade and human conflict [4]. Based on data from South Korean Customs, TRAFFIC Species in Danger Report between 1970-1993, 8.981 kg tiger bones found smuggled into South Korea, and more than (> 44\% (3.994 kg) came from Indonesia [5].

The illegal trade of the body parts of Sumatran tiger continues, evidenced by revealed Sumatran tiger trade activities in Riau and Medan Province in 2016 [6]. It is estimated that there are still many cases of persecution and illegal trade that cannot be disclosed. Samples of body parts of the Sumatran Tiger traded on the black market are sometimes challenging to identify. Some constraints are the conventional methods of identification and forensics. Standard methods based on morphology and immunology have limitations in the identification of samples that have been old and degraded [7]. For this reason, it is necessary to use the other identification method.

\footnotetext{
${ }^{*}$ Corresponding author

E-mail address: dewiroesma@sci.unand.ac.id
} 
Characterization is an activity to identify the essential characteristics of the particular species. One of the characters observed can be in the form of molecular aspects. The latest DNA-based identification method is developed for animal forensic investigation [8,9] and known as DNA barcoding technology, which was established in 2003 [10,11]. Currently, DNA barcoding has been used as a standard protocol for the rapid identification of animals and plants at the species level. DNA barcode consists of short pieces of DNA from standard genome regions. The cytochrome oxidase subunit 1 (CO1) gene is the gene used as the standard barcode for almost all groups of animals. The standard region of this gene in the mitochondrial is around 650 base pairs. C01 has proven to be very useful in identifying birds, butterflies, fish, flies, and many other animal groups. The advantage of using a C01 is that parts of the gene are short enough. The gene sorted quickly and cheaply to identify variations between species, very few deletions and insertions in the sequence, and mostly are conserved [10]. The DNA barcode is the sequence that can be used to identify different species. The barcode is the same way as a supermarket's scanner with the typical black lines of the Universal Product Code (UPC) that uses to identify our purchases.

One of the individuals at Sumatran Tiger Rehabilitation Center (PR-HSD) is a female with an individual identity called Bonita. Bonita was rehabilitated because of a conflict with humans in Riau, East Sumatra. After being rehabilitated, Bonita has been released to the jungle. At the same time, while Bonita is prepared to be released, we do the study to characterize DNA from Bonita's blood sample. The results of this study can be used to DNA barcode reference of other Sumatran Tigers especial for the forensic database to reveal the illegal trade.

\section{Material and methods}

\subsection{Sample sources and DNA extraction}

A blood sample of Bonita was collected at Sumatran Tiger Rehabilitation Center in Dharmasraya (PR-HSD). Bonita's blood put into a $1.5 \mathrm{ml}$ voculab tube. The samples were stored in -20oC. DNA extraction from blood sample following DNA Invitrogen PureLink ${ }^{\mathrm{TM}}$ Genomic DNA Kit protocol. The DNA extract was stored at -20oC for further analysis.

\subsection{Polymerase chain reaction (PCR) and DNA sequencing}

Mitochondrial DNA C01 segment was amplified with PCR using primers: forward C11020F (5' CCAGAAGTCTATATCTTAATCCCG 3') and reverse T11428R (5' GCTCCTATTGACAAG ACGTAG 3') [12]. DNA amplification was performed in $25 \mu \mathrm{l}$ reaction mixture containing: $11 \mu$ l Bioline master mix, $9 \mu \mathrm{l}$ nuclease free water, $1 \mu \mathrm{l}$ forward primer, $1 \mu \mathrm{l}$ reverse primer, and $3 \mu \mathrm{l}$ DNA template. The PCR process was set as follow: an initial denaturation at $960 \mathrm{C}$ for $1.0 \mathrm{~min}, 35$ cycles of denaturation at $96 \mathrm{oC}$ for $0.5 \mathrm{~min}$; annealing at $50 \mathrm{oC}$ for $0.5 \mathrm{~min}$; extension at $72 \mathrm{oC}$ for $1.5 \mathrm{~min}$; and final step at $72 \mathrm{oC}$ for $3.0 \mathrm{~min}$. PCR product was visualized on $1.2 \%$ agarose gels with ethidium bromide staining. The most powerful PCR product was sent to Firstbase Company Malaysia for nucleotide sequencing reactions.

\subsection{DNA sequence analysis}

The nucleotide sequence of the CO1 gene of Bonita was assembled and edited by visual examination with the DNA STAR program [13].

Table 1 List of comparative species

\begin{tabular}{llll}
\hline No & Species & Authors & GenBank Accession \\
\hline 1 & Panthera tigris sumatrae 1 & {$[17]$} & JF357969.1 \\
2 & Panthera tigris sumatrae 2 & {$[17]$} & JF357970 \\
3 & Panthera tigris altaica & {$[18$} & MH124112.1 \\
4 & Panthera tigris amoyensis 1 & {$[19]$} & HM589214 \\
5 & Panthera tigris tigris & {$[20]$} & JF357967 \\
6 & Panthera tigris amoyensis 2 & {$[19]$} & NC_014770 \\
7 & Panthera tigris corbetti & {$[20]$} & JF357971 \\
8 & Panthera leo & {$[21]$} & KF907306.1 \\
9 & Panthera onco & {$[22]$} & KF483864.1 \\
10 & Prionailurus bengalensis & {$[23]$} & KX857771.1 \\
11 & Prionailurus viverrinus & {$[24]$} & KR135742.1 \\
\hline
\end{tabular}


The DNA sequence was compared with the 11 sequences sampled (Table 1) from GenBank NCBI https://blast.ncbi.nlm.nih.gov/Blast.cgi using the Basic Local Alignment Search Tool (BLAST) program to measure the degree of data similarity. All of the sequences were edited using BioEdit program [14] and aligned using the Clustal X [15]. Data analysis using MEGA program version 7, and the genetic distances computed by applying the Kimura 2parameter (K2P) model of sequence evolution [16]. DNA barcode obtained by entering the C01 sequence into the BioRad DNA Barcode Generator site (biorad-ads.com/DNABarcodeWeb/).

\section{Results and discussion}

\subsection{Amplification fragment gene cytochrome oxidase subunit 1 (CO1)}

The results of the total DNA extraction were migrated to $1.2 \%$ agarose gel and viewed with UV trans-illuminator rays. The total DNA was used as a DNA template to amplification the C01 gene in the PCR process. Amplification of the mtDNA C01 region in Bonita's blood sample resulted in a single band measuring around $500 \mathrm{bp}$. Based on [17] the size of DNA fragments Panthera tigris sumatrae C01 gene is 957 bp, 657 bp in Panthera tigris [12], and 648 bp in Panthera tigris amoyensis [19].

\subsection{BLAST analysis and alignment}

The similarity of Bonita's C01 gene DNA sequence with GenBank data was analyzed with BLAST software. The results of the databases were used to assess the difference in nucleotide divergence within and between closely related species. The result showed that Bonita's sequence has a 99\% similarity with other Panthera tigris sumatrae. The DNA sequence of $\mathrm{CO} 1$ genes Bonita was $435 \mathrm{bp}$, occupies the complete mitochondrial genome of Panthera tigris sumatrae at position 6071-6505 bp. In line with the study of [20] who reported that the C01 gene of Panthera tigris sumatrae in mitochondrial DNA complete genome was at position 5351-6895 bp. The position of Bonita's sequence was in the 720 bp to 1155 bp of the C01 gene of Panthera tigris sumatrae species.

The total of 12 total sequence analyzed showed that there were $371 \mathrm{bp}(85.29 \%)$ conserved site and $64 \mathrm{bp}(14.71 \%)$ site variable that consists of $53 \mathrm{bp}(12.18 \%)$ parsimony site and $11 \mathrm{bp}(2.53 \%)$ singleton site. The composition of Bonita nucleotide bases were A (Adenine) 26\%, T (Thymine) 31.3\%, G (Guanine) 20.7\% and C (Cytosine) 22.1\%. Thymine is a dominant base of the CO1 gene of Bonita. The nucleotide base of Adenine + Thymine $(\mathrm{A}+\mathrm{T})$ was $57.9 \%$ while the nucleotide base of Guanin + Cytosine $(G+C)$ was $42.1 \%$. According to [25], the base of $G+C$ in the vertebrate group was lower than the $\mathrm{A}+\mathrm{T}$ base.

\subsection{Sequence and amino acid variation}

Molecular evolutionary genetics analysis (MEGA) version 7.0 software was used to translate all nucleotide bases from the sequenced of the $\mathrm{CO} 1$ gene into amino acids. Based on the results of amino acid translations, it is known that all codons translated to 145 amino acids with changes in four amino acids at the $8^{\text {th }}, 16^{\text {th }}, 46^{\text {th }}$, and $131^{\text {st }}($ Table 2$)$. One of them, the $8^{\text {th }}$ amino acid in Bonita individuals which Leucine (CTG) changes to Proline (CCG). The mutation CO1 sequence that made Leucine becomes Proline also was reported by [26] in Nycticebus species. The change occurred because of a missense mutation. According to [27], missense mutation occurs if the substitution of nucleotide bases obtained a new amino acid translation.

Table 2 also showed that the amino acid of Panthera onco was changed where Histidine (CAT) become Arginine (CGT). Kind of that mutation is a transversion where the purine nucleotide base changes to purine. Panthera leo had two changes in amino acids, first was transversion mutation that causes the conversion of the amino acid Isoleucine (ATC) to Serine (AGC) and second was transition mutations with the change of the amino acid Tyrosine (TAC) to Cysteine (TGC). The difference in the eighth amino acids in Bonita can make the characteristics of Bonita compared to other Panthera tigris. In overall, the composition of amino acids of the Bonita CO1 gene and the related species change rarely. 
Table 2 Variation of Bonita CO I amino acids and 11 comparative species

\begin{tabular}{|c|c|c|c|c|c|}
\hline No & Spesies & $\begin{array}{l}\text { L } \\
8\end{array}$ & $\begin{array}{l}H \\
16\end{array}$ & $\begin{array}{l}I \\
46\end{array}$ & $\begin{array}{l}Y \\
131\end{array}$ \\
\hline 1 & Panthera tigris altaica & . & $\cdot$ & . & . \\
\hline 2 & Panthera tigris tigris & . & . & . & . \\
\hline 3 & Panthera tigris sumatrae 1 & . & . & . & . \\
\hline 4 & Panthera tigris sumatrae 2 & . & . & . & . \\
\hline 5 & Panthera tigris amoyensis & . & . & . & . \\
\hline 6 & Panthera tigris corbetti & . & . & . & . \\
\hline 7 & Panthera tigris amoyensis & . & . & . & . \\
\hline 8 & Prionailurus bengalensis & . & . & . & . \\
\hline 9 & Prionailurus viverrinus & . & . & . & . \\
\hline 10 & Panthera leo & . & . & S & $\mathrm{C}$ \\
\hline 11 & Panthera onco & . & $\mathrm{R}$ & . & . \\
\hline 12 & Bonita B1 & $\mathrm{P}$ & . & . & . \\
\hline
\end{tabular}

\subsection{Phylogenetic analysis}

Phylogenetic analysis with distance genetic inter sequences can be used to show the relationship between analyzed species. The result of the phylogenetic tree for all sequence that made by using MEGA 7.0 program [16]. The tree was constructed by combining Maximum Likelihood (ML), Neighbour-joining (NJ), Minimum Evolution (ME) and Maximum Parsimony (MP) methods with 1000 replicate bootstraping (Figure 2).

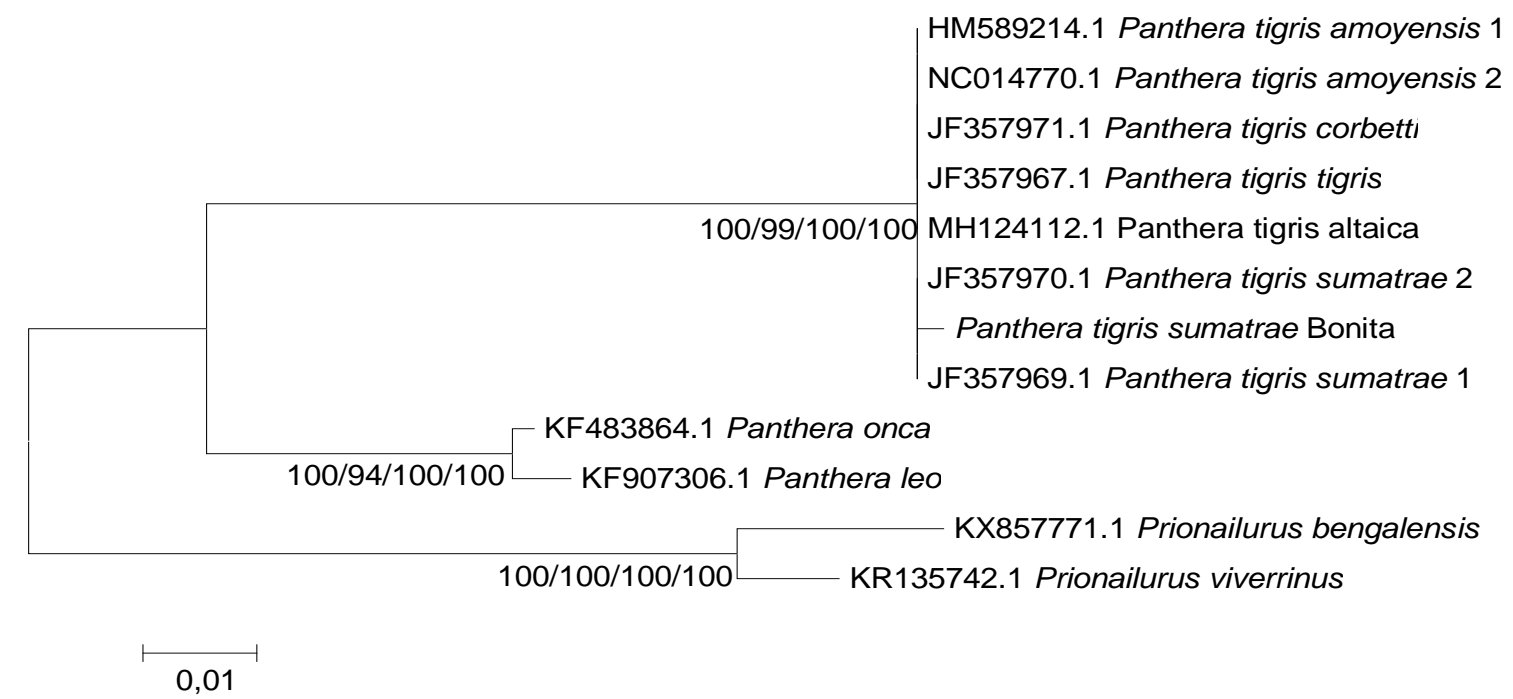

Figure 1 The ML phylogenetic tree of the C01 gene with bootstrapping of 1000 replicates (ME/ML/NJ/MP)

The phylogenetic tree (Figure 1.) showed that there were two main clusters obtained, $P$. tigris group and other $P$. tigris group (P. onca and P. leo) supported by highly bootstrap value 100/99/100/100 for ME/ML/MP, respectively. The First group consists of Bonita and the other P. tigris with 0.0-0.2\% sequence divergence. Referring to the research of [28], which states that individuals in the Felidae family were at the same species-level if they had a genetic distance was about 0\%-2.32\%. Therefore Bonita and member of P. tigris is differing in individual genetic variation level.

The sequence divergence between $P$. tigris and another group ( $P$. onca and $P$. leo) were 8.3-8.8\%. According to previous research [28], those value indicated that they are in different species in the same genus. The highest sequence divergence was between Bonita with Prionailurus bengalensis and Prionailurus viverrinus, which had $12.2 \%$ and $12.5 \%$ 
sequence divergences. Referring to [28], different species in the same Family in Felidae have a genetic distance of 10.3\%-39.9\%. From the present study, we obtained the DNA Barcode of Bonita ( $P$. tigris sumatrae). The sequence consists of 435 base pair of cytochrome oxidase subunit 1 (CO1) DNA mitochondrial gene. It has a specific site at $23^{\text {rd }}$ nucleotide position with changed of thymine to cytosine as well as Leucine became Proline at the eighth sequence of its amino acid.

\section{Conclusion}

From a total of $435 \mathrm{bp}$ in the CO1 gene, we obtained Bonita DNA Barcode and the specific site in the 23rd sequence nucleotide base with the change of thymine to cytosine.

\section{Compliance with ethical standards}

\section{Acknowledgments}

The author would like to thank the Directorate General of Learning and Student Affairs who have provided student research grant.Our thanks to Ir. Catrini Pratihari Kubontubuh, M.Arch. as the Executive Director of Arsari Djojohadikusumo Foundation's (YAD) and Dr. Erly Sukrismanto as the Head of Conservation of Natural Resources Office (KSDA) of West Sumatra for providing blood sample used in this study. Our appreciation goes to Managing Team of PKM-PE Andalas University, to our Rector, Dean, and Head of Departement for supporting us and also Dr. Djong Hon Tjong and Dyta, S.Si for help in the laboratory.

\section{Disclosure of conflict of interest}

There is no interest in the conflict between the authors of this piece of research work. The authors agreed and assigned in hand to all matter arise to this piece of research work.

\section{References}

[1] Dinerstein E, Loucks C, Heydlauff A, Wikramanayake E, Bryja G, Forrest J, Ginsberg J, Klenzendorf S, Leimgruber P, O’Brien T, Sanderson E, Seidensticker J and Songer M. (2006). Setting priorities for the conservation and recovery of wild tigers, 2005-2015.

[2] Borner M. (1978). Status and conservation of the Sumatran tiger. Carnivore, 1, 97-102.

[3] Soehartono T, Wibisono HT, Sunarto, Martyr D, Susilo HD, Maddox T and Priatna D. (2007). Strategi dan rencana aksi konservasi harimau sumatera (Panthera tigris sumatrae) 2007-2017, Departemen Kehutanan, Jakarta.

[4] Seidensticker J, Christie S and Jackson P. (1999). Introducing the tiger. Pages: 1-3 in J. Seidensticker, S. Christie, P. dan Jackson, editor. Riding the tiger: tiger conservation in human dominated landscape. Cambridge University Press, Cambridge. UK.

[5] Mills JA and Jackson P. (1994). Killed for a cure: a review of the worldwide trade in tiger bone. TRAFFIC International, Cambridge.

[6] Karokaro AS. (2016). Perdagangan kulit harimau terbongkar di Riau dan Medan.

[7] Alacs EA, Georges A, FitzSimmons NN and Robertson J. (2010). DNA detective: A review of molecular approaches to wildlife forensics. Forensic Sci Med Pathol, 6, 180-94.

[8] Dalton DL and Kotze A. (2011). DNA barcoding as a tool for species identification in three forensic wildlife cases in South Africa. Forensic Sci Int, 207, e51-e54.

[9] Carvalho CBV. (2014). DNA barcoding in forensic vertebrate species identification. Brazilian Jour. of Forensic Sci. Med. Law and Bioethics, 4(1), 12-23.

[10] Hebert PDN, Ratnasingham S and Waard JR. (2003). Barcoding animal life: cytochrome c oxidase subunit 1 divergences among closely related species. Proceedings of the Royal Society B, 270(1), S96-S99.

[11] Hebert PDN and Gregory TR. (2005). The promise of DNA barcoding for taxonomy. Systematic Biology, 54(5), 852-859.

[12] Luo SJ, Kim JH, Johnson WE, Walt JVD, Martenson J, Yuhki N, Miquelle DG, Uphyrkina O, Goodrich JM, Quigley HB, Tilson R, Brady G, Martelli P, Subramaniam V, McDougal C, Hean S, Huang SQ, Pan W, Karanth UK, Sunquist M, 
Smith JLD and O’Brien SJ. (2004). Phylogeography and genetic ancestry of tigers (Panthera tigris). PLoS Biol, 2, 2275-2293.

[13] Burland TG. (2000). DNAstar's laser gene sequence analysis software. Methods Mol Biol, 132, 71-91.

[14] Hall TA. (1999). BioEdit; a user-friendly biological sequence alignment editor and analysis program for windows 95/98/nt. Nucleic Acids Symposium Series, 41, 95-98.

[15] Larkin MA, Blackshields G, Brown NP, Chenna R, McGettingan PA, McWilliam H, Valentin F, Wallace IM, Wilm A, Lopez R, Thompson JD, Gibson TJ and Higgins DG. (2007). Clustal W and Clustal X version 2.0. Bioinformatics, 23, 2947-2948.

[16] Kumar S, Stecher G and Tamura K. (2016). MEGA 7 Molecular evolutionary genetics analysis version 7.0 for bigger datasets. Molecular Biology and Evolution, 33, 1870-1874.

[17] Kitpipit T, Tobe SS, Kitchener AC, Gill P and Linacre A. (2011). The development and validation of a single snapshot multiplex for tiger species and subspecies identification implication for forensic purpose. Forensic Science International, Genetics, 250-257.

[18] Zhou Y, Ma J, Liu D and Zhu H. (2018). Parallel tagged amplicon sequencing of 36 captive amur tigers mitochondrial genome using the Illumina HiSeq platform. Unpublished.

[19] Zhang W, Yue B, Wang X., Zhang X, Xie Z, Liu N, Fu W, Yuan Y, Chen D, Fu D, Zhao B, Yin Y, Yan X, Wang X, Zhang R, Liu J, Li M, Tang Y, Hou R and Zhang Z. (2011). Analysis of variable sites between two complete south china tiger (Panthera tigris amoyensis) mitochondrial genomes. Mol. Biol. Rep, 38 (7), 4257-4264.

[20] Kitpipit T and Linacre A. (2012). The complete mitochondrial genome analysis of the tiger (Panthera tigris). Mol Biol Rep, 39, 5745-5754.

[21] Xiang ZF and Deng LX. (2014). Whole mitochondrial genom of the white african lion. Mitochondrial DNA, 1-2.

[22] Caragiulo A, Dougherty E, Rabinowitz S and Amato G. (2013). Complete mitochondrial genome sequence of the jaguar (Panthera onca). Mitochondrial DNA, 1-2.

[23] Patel RP, Wutke S, Lenz D, Mukherjee S, Ramakrishnan U, Veron G, Fickel J, Wilting A and Forster DW. (2017). Genetic structure and phylogeography of the leopard cat (Prionailurus bengalensis) Inferred from Mitochondrial Genomes. J. Hered, 1-12.

[24] Patel RP. (2016).Two species of the genus Catopuma with diverging histories: An island endemic forest specialist and a wide-spread habitat generalist. R Soc Open Sci.

[25] Saccone C, de Giorgi C, Gissi C, Pesole G and Reyes A. (1999). Evolutionary genomics in metazoa: the mitochondrial DNA as a model system. Gene, 238, 195- 209.

[26] Wirdateti, Indriana E and Handayani. (2016). Analisis sekuen DNA mitokondria cytochrom oxidase I (COI) mtDNA pada kukang (Nycticebus spp) sebagai penanda guna pengembangan identifikasi spesies. Jurnal Biologi Indonesia, 12(1), 119-128.

[27] Lodish HA, Berk SL, Zipursky P, Matdusaira D, Baltimore and J. Darnell. (2000). Molecular cell biology, 4th edition. W. H Freeman and Company, New York.

[28] Pietsch SJ. (2011). DNA barcoding \& multi-isotopic fingerprinting: A novel forensic toolbox for the rapid identification of illegal trade in endangered wildlife species. Faculty of Mathematics and Natural Sciences, University of Bonn.

\section{How to cite this article}

Ashrifurrahman, Fadhlullah A, Ericca C, Simamora S, Novarino W and Roesma DI. (2019). Characteristic of C01 gene in "Bonita", one of the female tiger Panthera tigris sumatrae in East Sumatra. World Journal of Advanced Research and Reviews, 4(2), 43-48. 